\title{
Effect of $\beta$-Eudesmol on NQO1 suppression-enhanced sensitivity of cholangiocarcinoma cells to chemotherapeutic agents
}

Pimradasiri Srijiwangsa ${ }^{1}$, Saranyoo Ponnikorn ${ }^{1}$ and Kesara Na-Bangchang ${ }^{1,2^{*}}$

\begin{abstract}
Background: Cholangiocarcinoma (CCA), an epithelial malignancy of the biliary tree, is one of the aggressive cancers with poor prognosis and unsatisfactory response to chemotherapy with acquired resistance. NAD(P)Hquinone oxidoreductase 1 (NQO1), an antioxidant/detoxifying enzyme, plays important roles in chemo-resistance and proliferation in several cancer cells. The study aimed to investigate the inhibitory effect of $\beta$-eudesmol on NQO1 enhanced chemotherapeutic effects of 5-fluorouracil (5-FU) and doxorubicin (DOX) in the high NQO1expressing human CCA cell line, NQO1-KKU-100. In addition, the molecular events associated with the inhibition of the cell proliferation, cell migration, and induction of apoptosis were investigated.

Methods: Human CCA KKU-100 cells were exposed to $\beta$-eudesmol at various concentrations. NQO1 enzyme activity and protein expression were measured by enzymatic assay and Western blot analysis, respectively. Sulforhodamine B (SRB) assay and wound healing assay were performed to detect the inhibitory effect of $\beta$ eudesmol on cell proliferation, cell migration, and sensitivity to 5-FU and DOX. Apoptotic induction was detected by flow cytometry with annexin V/PI and DAPI nuclear staining. Caspase 3/7 activation was determined by fluorescence microscopy. The mechanism of enhanced chemo-sensitivity was evaluated by Western blot analysis.

Results: $\beta$-Eudesmol significantly suppressed NQO1 enzyme activity (both in KKU-100 cells and cell lysates) and protein expression in KKU-100 cells in a concentration-dependent manner. $\beta$-Eudesmol exhibited potent cytotoxicity on KKU-100 cells with mean \pm SD IC 50 values of $47.62 \pm 9.54$ and $37.46 \pm 12.58 \mu \mathrm{M}$ at 24 and $48 \mathrm{~h}$, respectively. In addition, it also potentiated the cytotoxic activities and inhibitory activities of 5-FU and DOX on cell migration through induction of cell apoptosis and activation of caspase 3/7. Western blot analysis suggested that $\beta$-eudesmol enhanced chemosensitivity was associated with the suppression of NQO1 protein and activation of $\mathrm{Bax} / \mathrm{BCl}-2$ protein expression ratio in CCA cells.

Conclusions: $\beta$-Eudesmol may serve as a potential anti-CCA candidate particularly when used in combination with conventional chemotherapeutics. The mechanisms involved may be mediated via NQO1 suppression-related apoptosis pathway.
\end{abstract}

Keywords: Cholangiocarcinoma, NAD(P)H-quinone oxidoreductase 1, $\beta$-Eudesmol, 5-Fluorouracil, Doxorubicin, Apoptosis, Migration

\footnotetext{
* Correspondence: kesaratmu@yahoo.com

${ }^{1}$ Chulabhorn International College of Medicine, Thammasat University,

(Rangsit Campus), Pathum Thani 12121, Thailand

${ }^{2}$ Center of Excellence in Pharmacology and Molecular Biology of Malaria and

Cholangiocarcinoma, Chulabhorn International College of Medicine,

Thammasat University, Pathum Thani, Thailand
}

(c) The Author(s). 2018 Open Access This article is distributed under the terms of the Creative Commons Attribution 4.0 International License (http://creativecommons.org/licenses/by/4.0/), which permits unrestricted use, distribution, and reproduction in any medium, provided you give appropriate credit to the original author(s) and the source, provide a link to the Creative Commons license, and indicate if changes were made. The Creative Commons Public Domain Dedication waiver (http://creativecommons.org/publicdomain/zero/1.0/) applies to the data made available in this article, unless otherwise stated. 


\section{Background}

Cholangiocarcinoma (CCA) is an extremely aggressive malignant tumor of the bile duct that becomes one of the major health problems worldwide. It is originating from the epithelial cells of the extrahepatic or intrahepatic bile ducts [1]. The northeastern region of Thailand including countries around Mekong basin are documented as areas with highest CCA incidence in the world [2, 3]. Epidemiological and experimental studies provide evidence that chronic inflammation and cell injury as a consequence of infection with the liver flukes Opisthorchis viverrini or Chlonorchis sinensis is the main risk factor of CCA [4]. The diagnosis of CCA is challenging because most patients are present with progressive and advanced stages resulting in disease poor prognosis [5]. Currently, management of CCA remains a challenge because the only occasional therapy is surgical resection. Chemoresistance is the major obstacle in the treatment of CCA particularly in unresectable tumors [6]. Multiple mechanisms involved in resistance of CCA to chemotherapeutic agents have been proposed. These include alteration of drug metabolizing enzymes, efflux transporters, cytoprotective enzymes, or derangement of intracellular signaling system [7, 8]. Novel effective therapy to overcome the chemoresistance of CCA is urgently needed.

NAD(P)H-quinone oxidoreductase 1 (NQO1; EC 1.6.5.2) is mainly a cytosolic phase II detoxification enzyme that reduces quinones to hydroquinones and thus bypassing the toxic semiquinone intermediates. The resultant hydroquinones undergo further conjugation and excretion [9]. NQO1 is ubiquitously expressed at low basal levels in all types of normal human tissues except liver through Nrf2 dependent pathway and proteasome degradation [10, 11]. The enzyme is induced along with a battery of defensive enzymes in response to cellular stress to prevent carcinogenesis process in body tissues through its free radical scavenging activity $[9,12,13]$. Conversely, the expression of NQO1 has been found to be increased in cancers of lung [14], pancreas [15], breast [16], thyroid [17], stomach [18], and bile duct (CCA) [19]. It is hypothesized that high level of NQO1 expression promotes carcinogenesis and cancer progression while also making cells more resistant to anticancer drugs particularly oxidative stress inducers. The critical role of NQO1 as a promising target for cancer chemotherapy has been demonstrated in various studies. Inhibition of NQO1 activity by dicoumarol, the pharmacological NQO1 inhibitor, was shown to suppress urogenital cancer cell growth and potentiate cytotoxicity of doxorubicin and cisplatin [20, 21]. In CCA, dicoumarol was shown to potentiate gemcitabine-induced cytotoxicity in the high NQO1-expressing CCA [22]. Furthermore, knocking down of NQO1 gene expression by small interfering RNA (siRNA) in the high NQO1-expressing CCA cells was shown to enhance the cytotoxic effect of 5-fluorouracil, doxorubicin, and gemcitabine [23]. Searching for specific NQO1 inhibitors would therefore be one of the promising approaches for discovery and development of new chemotherapeutics for CCA. A large number of moderate to potent NQO1 inhibitors from natural and synthetic sources have been reported including flavonoids, coumarins, curcumin, and ES936, of which the most demonstrative inhibitors are dicoumarol and ES936 [24-26]. Dicoumarol acts by completing with $\mathrm{NAD}(\mathrm{P}) \mathrm{H}$ and thereby preventing the reduction of FAD in cells. The compound is commonly used to investigate the inhibitory effect on NQO1 activity and its consequences in several cell types. Based on X-crystallography, the conformational change of the amino acid residues Tyr128 and Phe232 located in the catalytic pocket of NQO1 have been demonstrated upon binding of dicoumarol [27]. Unlike dicoumarol, flavonoids have been identified as strong NQO1 inhibitors through competitive inhibition of $\mathrm{NAD}(\mathrm{P}) \mathrm{H}$ [27]. Preliminary molecular dynamic studies suggested that flavonoids bind to different active site of NQO1 from that of dicoumarol; the 7-hydroxyl moiety of the flavonoids interacts with His161 residue in the active site [28]. The inhibition of NQO1 by flavonoids is pointing at a mechanism contradicting the proven beneficial properties of these phytochemicals. Novel NQO1 inhibitors are being identified by a structure-based or mechanism-based approach using reference NQO1 inhibitors.

$\beta$-Eudesmol is a one of the major constituents of the rhizome of Atractylodes lancea (Thunb) DC. (AL: Khod-Kha-Mao or Cang Zhu) of the Compositae family. It is the common medical plant used in Thai and Chinese traditional medicine for treatment of fever, colds, flu, sore throat, rheumatic diseases, digestive disorders, night blindness, and influenza [29, 30]. Various pharmacological activities of AL as well as its active compounds $\beta$-eudesmol, atracylodin, hinesol and atracylon have been demonstrated [26]. With regard to anticancer activity, inhibitory effect of AL on gastric and colon cancer cells were demonstrated [31, 32]. In addition, the potential role of AL and $\beta$-eudesmol in CCA has previously been demonstrated both in vitro and in vivo models [33-35]. Both exhibited promising inhibitory activity in CCA-xenografted nude mice with a marked reduction of tumor size and lung metastasis, as well as prolongation of survival time [34]. $\beta$-Eudesmol is a member of the class of compounds known as eudesmane, isoeudesmane or cycloeudesmane sesquiterpenoids [36]. Sesquiterpenoids were shown to inhibit phase II detoxification enzymes including superoxide dismutase (SOD), and UDP-glucuronosyltransferase (UGT). The cytotoxic and apoptotic activities on HL-60 cells of sesquiterpenolides (atractylenolide I, AT-I) from the dried rhizome of 
Atractylodes ovata were shown to be through inhibition of $\mathrm{Cu}-\mathrm{Zn}$-SOD activity [37]. In addition, the inhibitory effect on UGT activity of the sesquiterpenoid xanthorrhizol, a major component of the essential oil of Curcuma xanthorrhiza was demonstrated in an in vivo study [38]. Nevertheless, the cytotoxic activity of sesquiterpenoids through modulation of NQO1 or other detoxifying enzymes has not been fully investigated. We have previously reported that $\beta$-eudesmol exerts potent growth inhibitory activity on CCA cells which might be linked to its suppressive effect on heme oxygenase-1 (HO-1) production, STAT1/3 activation, and NF-kB downregulation [39]. Based on this information together with the complex multidirectional biological activity of $\beta$-eudesmol, it is also worth investigating its activity on the NQO1 target which is highly expressed in CCA. In the present study, the effect of $\beta$-eudesmol on NQO1 suppression-enhanced chemotherapeutic effects of 5-fluorouracil (5-FU) and doxorubicin (DOX) was observed in the human CCA cell line, KKU-100. In addition, the molecular events associated with the inhibition of cell proliferation, cell migration, and induction of apoptosis were investigated.

\section{Methods}

\section{Chemical and reagents}

The cell culture medium Ham's F12, fetal bovine serum, $0.25 \%$ trypsin-EDTA, and penicillin-streptomycin solution were purchased from Gibco BRL Life Technologies (Grand Island, NY, USA). $\beta$-Eudesmol and 5-fluorouracil (5-FU) were purchased from Wako Pure Chemical Industries Ltd. (Osaka, Japan). Doxorubicin hydrochloride (DOX) was obtained from Boryung Pharm (Seoul, South Korea). Dimethyl sulfoxide (DMSO) was purchased from Lab-Scan Analytical Science (Dublin, Ireland). $\beta$-Eudesmol was dissolved in $100 \%$ ethanol. 5-FU and DOX were dissolved in $100 \%$ DMSO. Concentrations of both solvents used in all experiments were less than $1 \%(v / v)$.

All reagents used for NQO1 activity assay and sulforhodamine B (SRB) assay were obtained from Sigma Chemical Co. Ltd. (St. Louis, MO, USA). The primary rabbit polyclonal IgG NQO1 antibody (1:2500) (ab34173) was purchased from Abcam (Cambridge, MA, USA). The rabbit polyclonal IgG Bax (1:2500) (\#sc-493), mouse monoclonal IgG Bcl-2 (1:1000) (\#sc-7382) and mouse monoclonal IgG $\beta$-actin (1:2500) (\#sc-1616), and the secondary horseradish peroxidase (HRP)-linked antibodies (goat anti-rabbit IgG; \#sc-2004 and goat anti-mouse IgG; \#sc-2005 at 1:5000 dilution) were obtained from Santa Cruz Biotechnology, Inc. (California, USA). The Amersham ${ }^{\mathrm{Tm}}$ ECL $^{\mathrm{Tm}}$ Prime Western Blotting Detection Reagent was obtained from Amersham Biosciences Crop. (NJ, USA). Annexin V-FITC apoptosis detection kit (Cat no. 420201) and 4'-6-diamidino-2-phenylindole
(DAPI) (Cat no. 422801) were purchased from BioLegend Inc. (San Diego, CA, USA). CellEvent ${ }^{\mathrm{TM}}$ Caspase-3/7 green detection reagent (Cat no. C10723) was obtained from Invitrogen (Thermo Fisher Scientific Inc., Massachusetts, USA).

\section{Cell lines and cell culture}

The human CCA cell line, KKU-100, with a high expression level of NQO1 was used in the study [23]. The cell was originally derived from intrahepatic CCA tissue of a patient and was kindly provided by Professor Banchob Sripa, Department of Pathology, Faculty of Medicine, Khon Kean University. The cell was routinely cultured in complete medium consisting of Ham's F12 supplemented with $10 \%$ fetal calf serum, $12.5 \mathrm{mM} \mathrm{HEPES}$ ( $\mathrm{pH}$ 7.3), $100 \mathrm{U} / \mathrm{mL}$ penicillin G, and $100 \mu \mathrm{g} / \mathrm{mL}$ streptomycin and maintained at $37{ }^{\circ} \mathrm{C}$ under an atmosphere of $5 \% \mathrm{CO}_{2}$. Culture medium was renewed every 3 days. Cells were trypsinized with $0.25 \%$ trypsin-EDTA and subcultured in the same culture medium.

\section{$\mathrm{NAD}(\mathrm{P}) \mathrm{H}$-quinone oxidoreductase 1 (NQO1) activity assay} The NQO1 activity assay was performed according to the previously described method [40]. In brief, the KKU-100 cells were cultured overnight at $37{ }^{\circ} \mathrm{C}$ in a 96-well microtiter plate $\left(7.5 \times 10^{3}\right.$ cells/well $)$. The cells were exposed to various concentrations of $\beta$-eudesmol $(0,1,10,30$, and $100 \mu \mathrm{M})$ and dicoumarol $(1 \mu \mathrm{M})$, a potent pharmacological NQO1 enzyme inhibitor $\left(37^{\circ} \mathrm{C}\right.$, $24 \mathrm{~h}$ ). Cells were lysed with $50 \mu \mathrm{L}$ of $0.8 \%$ digitonin in $2 \mathrm{nM}$ EDTA with agitation for $10 \mathrm{~min}$. The assay was performed using menadiol and MTT [3-(4, 5-dimethylthiazol-2-yl)-2,5-diphenyltetrazolium bromide] in the substrate coupling reaction and measured as rate-kinetics at the wavelength of $620 \mathrm{~nm}$. To further investigate the direct effect of $\beta$-eudesmol on NQO1 activity, $\beta$-eudesmol $(1-100 \mu \mathrm{M})$ was added to KKU-100 cell lysates. Following incubation $\left(37^{\circ} \mathrm{C}, 15 \mathrm{~min}\right)$, the NQO1 activity of the lysates was determined. Using the extinction coefficient of MTT formazan of 11,300 $\mathrm{M}^{-1} \mathrm{~cm}^{-1}$ at $620 \mathrm{~nm}$ and correction for the light path of the microplate, activity of NQO1 is expressed as $\mathrm{nmol} / \mathrm{min} / \mathrm{mg}$ protein. The assay was performed as three independent experiments, triplicate each.

\section{Western blot analysis}

Western blot analysis was performed to determine the expression levels of NQO1 and apoptotic proteins following exposure to various concentrations of $\beta$-eudesmol with or without 5-FU or DOX. In brief, KKU-100 cells were washed with PBS and lysed with $1 \times$ cell lysis buffer $\left(4{ }^{\circ} \mathrm{C}\right)$ containing $1 \mathrm{mmol} / \mathrm{L}$ dithiothreitol (DTT), and $0.1 \mathrm{mmol} /$ $\mathrm{L}$ phenylmethylsulfonyl fluoride (PMSF) with vigorous shaking. Following centrifugation at $12,000 \mathrm{~g}$ for $30 \mathrm{~min}$, the cell supernatant was collected and stored at $-80{ }^{\circ} \mathrm{C}$ 
until use. The sample was mixed with $5 \times$ loading dye buffer and heated at $90{ }^{\circ} \mathrm{C}$ for $10 \mathrm{~min}$. Proteins were separated by electrophoresis (in 10\% SDS-polyacrylamide gel) and transferred to polyvinylidene difluoride (PVDF) membranes (180 mA, $1 \mathrm{~h})$. The PVDF membranes were blocked with $5 \%(w / v)$ skimmed milk powder in PBS and $0.1 \%$ Tween- $20\left(25{ }^{\circ} \mathrm{C}, 1 \mathrm{~h}\right)$ and incubated overnight at $4{ }^{\circ} \mathrm{C}$ with primary antibodies diluted with PBS and 0.1\% Tween-20. The antibodies used were as follows: rabbit polyclonal IgG NQO1 (1:2500), rabbit polyclonal IgG Bax (1:2500), mouse monoclonal IgG Bcl-2 (1:1000) and mouse monoclonal IgG $\beta$-actin (1:2500). The primary antibody was removed and the blots were extensively washed with $\mathrm{PBS} /$ Tween-20 and incubated $\left(25{ }^{\circ} \mathrm{C}, 2 \mathrm{~h}\right)$ with the secondary antibodies (horseradish peroxidase goat anti-mouse IgG and goat anti-rabbit IgG at 1:5000 dilution in PBS buffer). After removal of the secondary antibody and washing with PBS/Tween-20, the blots were incubated with the ECL substrate solution. Densities of the specific bands of NQO1, Bcl-2, Bax, and $\beta$-actin were visualized and captured by Imagequant ${ }^{\mathrm{mt}}$ LAS4000.

\section{Cell cytotoxicity assay}

Cytotoxicity testing was performed using the sulphorhodamine B (SRB) assay. Briefly, KKU-100 cells were seeded onto a 96-well microtiter plate $\left(7.5 \times 10^{3}\right.$ cells/well) and incubated overnight at $37{ }^{\circ} \mathrm{C}$. Cells were exposed to various concentrations of the test compounds $(200 \mu \mathrm{L})$ for specified periods as follows: (i) $\beta$-eudesmol alone $(0,1,10,30$, and $100 \mu \mathrm{M}$ ) for 24 and $48 \mathrm{~h}$; (ii) $30 \mu \mathrm{M} \beta$-eudesmol in combination with 5 -FU $(0,3,10,30$, and $100 \mu \mathrm{M})$ for 24 and $48 \mathrm{~h}$; and (iii) $30 \mu \mathrm{M} \beta$-eudesmol in combination with DOX (0, $0.1,0.01,1$, and $10 \mu \mathrm{M}$ ) for 24 and $48 \mathrm{~h}$. The cells were fixed with $100 \mu \mathrm{L}$ of ice-cold $10 \%$ trichloroacetic acid (TCA) at $4{ }^{\circ} \mathrm{C}$ for at least $1 \mathrm{~h}$. TCA was removed and the cells were washed 5 times with distilled water. After $10 \mathrm{~min}$ of air drying, $50 \mu \mathrm{L}$ of $0.4 \%$ sulforhodamine in $1 \%$ acetic acid was added and the cell suspension was incubated at $25{ }^{\circ} \mathrm{C}$ for $30 \mathrm{~min}$. Cells were rinsed 3-4 times with $1 \%$ acetic acid and air dried at $25{ }^{\circ} \mathrm{C}$ for $1 \mathrm{~h}$. Finally, the adhered cells were dissolved in $10 \mathrm{mM}$ Tris base $(200 \mu \mathrm{L})$ and the plate was shaken for $20 \mathrm{~min}$. The absorbance of cell suspension was measured at the wavelength of $540 \mathrm{~nm}$. Cell growth inhibition was expressed in term of percentage of untreated control absorbance. The $\mathrm{IC}_{50}$ (concentration that inhibits cell growth by $50 \%$ ) was estimated from concentration-response curve analysis using Prism 5 program (GraphPad Software, San Diego, CA, USA).

\section{Cell migration by wound healing assay}

Cell migration was assessed using wound healing assay according to the previously described method [41].
Briefly, KKU-100 cells $\left(1.5 \times 10^{5}\right.$ cells/well $)$ were seeded onto a 24-well microtiter plate and allowed to grow overnight at $37{ }^{\circ} \mathrm{C}$ in Ham's F12 medium supplemented with $10 \%$ fetal calf serum. A scratch wound was made using a sterile $200 \mu \mathrm{L}$ pipette tip and the scratched cells were washed twice with PBS to remove any detached cells. Cells were exposed to various concentrations of the test compounds $(200 \mu \mathrm{L})$ for $48 \mathrm{~h}$ as follows: (i) $\beta$-eudesmol $(30 \mu \mathrm{M})$ in combination with 5-FU $(30 \mu \mathrm{M})$; and (ii) $\beta$-eudesmol $(30 \mu \mathrm{M})$ in combination with DOX $(0.1 \mu \mathrm{M})$. The width of the wound outline was monitored under a phase-contrast microscope. The closing of the scratched wound was determined by capturing the denuded area along the scratch using Image-Pro Plus software (Media Cybernetics, LP, USA).

\section{Cell apoptosis analysis and caspase $3 / 7$ activation}

The potentiating effect of $\beta$-eudesmol $(30 \mu \mathrm{M})$ on 5 -FU $(30 \mu \mathrm{M})$ or DOX $(0.1 \mu \mathrm{M})$-induced apoptosis in KKU-100 cells was investigated using Annexin V-FITC Apoptosis Detection Kit. Following a $24 \mathrm{~h}$ incubation, cells were washed twice with cold BioLegend's cell staining buffer and resuspended in Annexin $\mathrm{V}$ binding buffer to obtain the cell density of $5 \times 10^{5}$ cells $/ \mathrm{mL}$. FITC Annexin $\mathrm{V}$ and propidium iodide solution (5 $\mu \mathrm{L}$ each) were added and the cells were incubated at $25{ }^{\circ} \mathrm{C}$ for $15 \mathrm{~min}$ in the dark. Apoptotic cells were analyzed by flow cytometry (BD FACSCan to II, BD Biosciences, San Joes, CA, USA). Intact nuclei within apoptotic cells were stained and observed by DAPI method according to the manufacturer's procedure. Following exposure to $\beta$-eudesmol in combination with 5 -FU or DOX for $24 \mathrm{~h}$, KKU-100 cells $\left(1.5 \times 10^{5}\right.$ cells/well of a 24 well microtiter plate) were washed with PBS, fixed with iced methanol for $10 \mathrm{~min}$, and stained with $1 \mu \mathrm{g} / \mathrm{mL}$ DAPI for $15 \mathrm{~min}\left(25^{\circ} \mathrm{C}\right.$ in the dark). Results are expressed with complementary nuclear morphological observations gathered using fluorescence microscope $\left(\mathrm{ZOE}^{\mathrm{m}}\right.$ fluorescent Cell imager: BIO-RAD, California, USA).

The effects of $\beta$-eudesmol in combination with 5-FU or DOX on stimulation of caspase 3 and caspase 7 of the apoptosis pathway in the KKU-100 cells were investigated using CellEvent ${ }^{\mathrm{Tw}}$ Caspase 3/7 Green detection assay. Caspase 3/7 Green is a novel fluorogenic substrate that activates caspase 3 and caspase 7 which constitute a hallmark of the apoptotic process. The reagent consists of a four amino acid peptide (DEVD) conjugated to a nucleic acid binding dye. This cell-permeant substrate is intrinsically non-fluorescent because the DEVD peptide inhibits the ability of the dye to bind to DNA. After activation of caspase 3 or caspase 7 in apoptotic cells, the DEVD peptide is cleaved, enabling the 
dye to bind to DNA and produce a bright, fluorogenic response with an absorption/emission maxima of $\sim 502$ / $530 \mathrm{~nm}$. The KKU-100 cells $\left(1.5 \times 10^{5}\right.$ cells $)$ were mixed with the test compounds as described above and seeded onto each well of a 24-well culture plate. Following incubation $\left(37{ }^{\circ} \mathrm{C}\right.$ under $5 \% \mathrm{CO}_{2}$ for $24 \mathrm{~h}$ ), cells were washed with PBS and fixed with iced methanol $(10 \mathrm{~min})$. CellEvent ${ }^{\mathrm{Tm}}$ caspase $3 / 7$ Green Detection Reagent was added to each well at a final concentration of $10 \mathrm{mM}$ and incubated at $25{ }^{\circ} \mathrm{C}$ for $30 \mathrm{~min}$ in the dark. Cells were observed under a light and a fluorescence microscope (ZOE ${ }^{\mathrm{m}}$ fluorescent Cell imager: BIO-RAD, California, USA).

\section{Statistical analysis}

Statistical analysis was performed using the Prism 5 program (GraphPad Software, San Diego, CA, USA). Quantitative data are expressed as mean \pm SD of three independent assays, triplicate each. Comparison of difference in data of two dependent quantitative groups was performed using paired $\mathrm{t}$-test at a statistical significance level of $p<0.05$.

\section{Results}

The sensitivity of NQO1 to $\beta$-eudesmol

$\beta$-Eudesmol at the concentration range $1-100 \mu \mathrm{M}$ significantly inhibited NQO1 enzyme activity of the KKU-100 cells in a concentration-dependent manner (Fig. 1a). Dicoumarol was the most potent inhibitor of NQO1 activity $(77.96 \%$ inhibitory effect at $1 \mu \mathrm{M})$. For $\beta$-eudesmol, significant inhibitory activity on NQO1 activity was observed at 30 and $100 \mu \mathrm{M}$ (37.68 and 50.06\%, respectively). $\beta$-Eudesmol also produced an inhibitory effect on the NQO1 activity of the cell lysates in a concentration-dependent manner (Fig. 1b). The inhibitory effect occurred within 15 min of exposure. At the lowest concentration $(1 \mu \mathrm{M})$, the enzyme activity was inhibited by $71.86 \%$ and almost complete inhibitory effect $(95.56 \%)$ occurred at the highest concentration $(100 \mu \mathrm{M})$. Furthermore, Western blot analysis was performed to verify whether the suppressive action of $\beta$-eudesmol towards NQO1 activity was due to direct inhibition of the enzyme activity or modulation of its expression. These results showed that the NQO1 protein expression was significantly suppressed only when the cells were exposed to the highest concentration $(100 \mu \mathrm{M})$ of $\beta$-eudesmol (Fig. 1c).

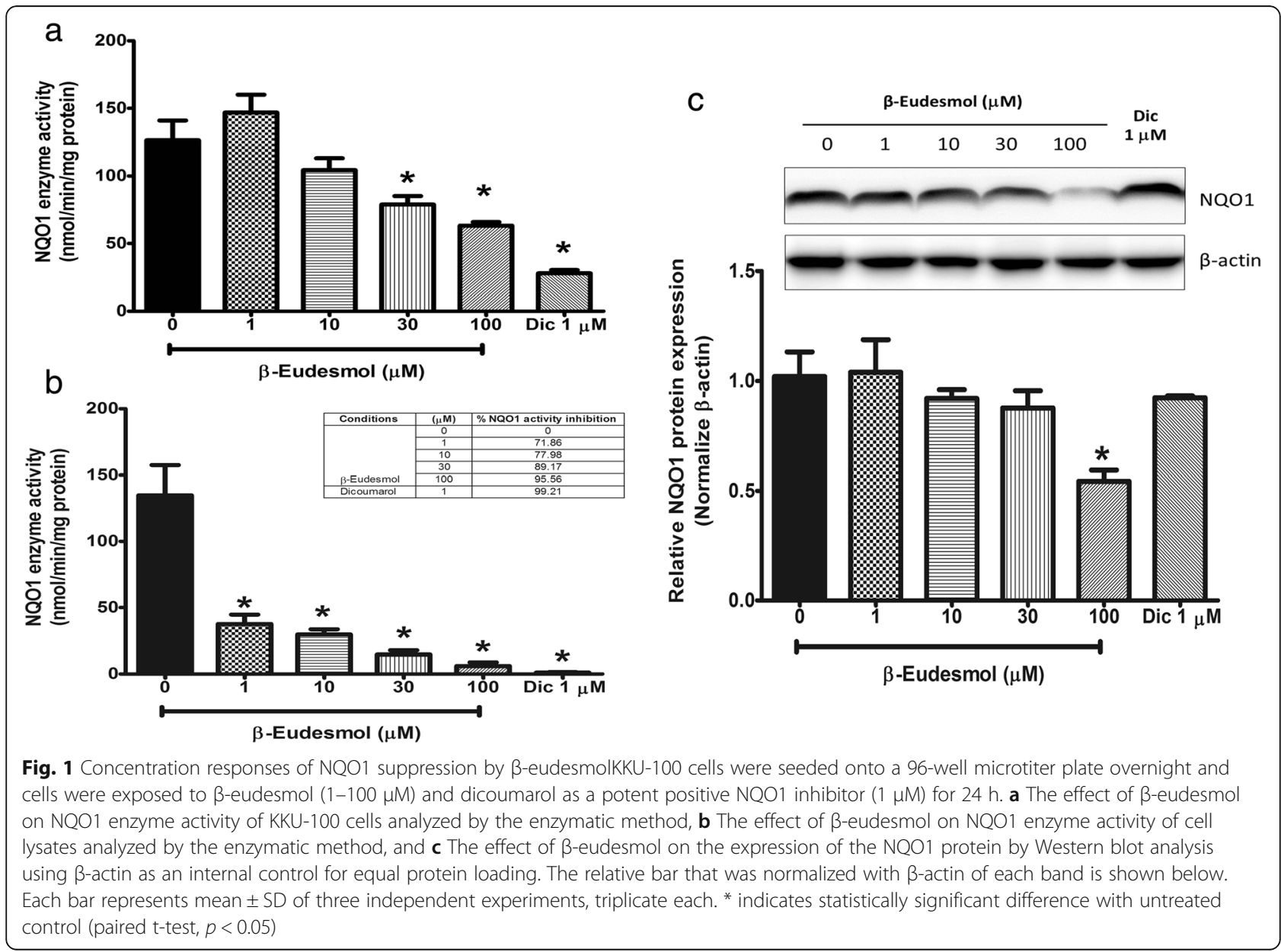


Potentiating effect of $\beta$-eudesmol on cytotoxic activities of 5-FU and DOX

To investigate whether the inhibitory activity of $\beta$-eudesmol on NQO1 activity and protein expression in the CCA cells resulted in an enhanced sensitivity of the cells to chemotherapeutic agents, the KKU-100 cells were incubated with $\beta$-eudesmol in the absence and presence of 5 -FU or DOX for 24 or $48 \mathrm{~h}$. $\beta$-Eudesmol potently inhibited cell growth with mean $( \pm \mathrm{SD}) \mathrm{IC}_{50}$ of $47.62 \pm 9.54$ and $37.46 \pm 12.58 \mu \mathrm{M}$ following 24 and $48 \mathrm{~h}$ exposure (Fig. 2a). The concentration of $\beta$-eudesmol below the $\mathrm{IC}_{50}(30 \mu \mathrm{M})$ was therefore used in subsequent

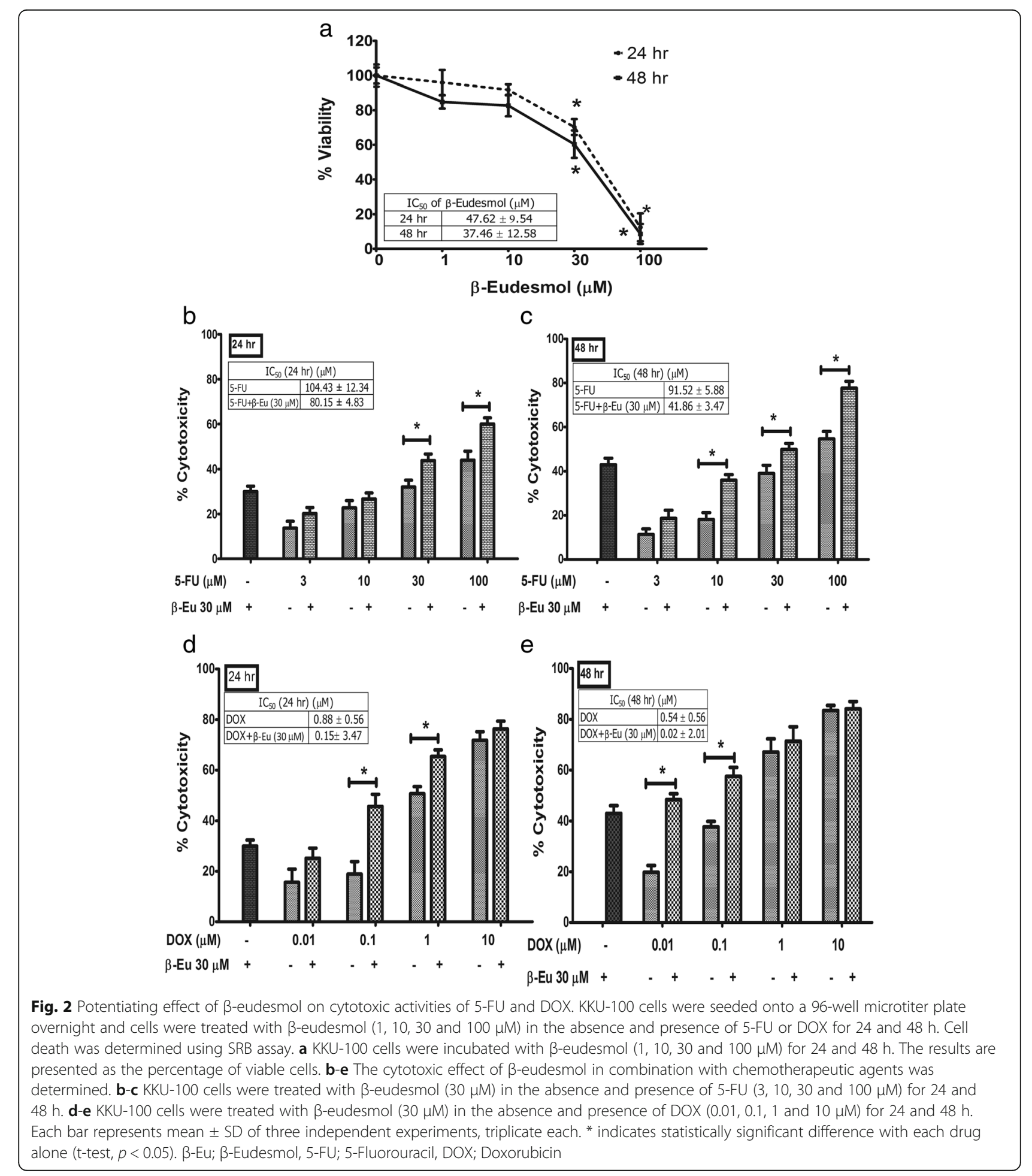


experiments (potentiating effect on cytotoxic activities, inhibitory effect on cells migration, and enhancing the effect on cell apoptosis) to avoid the complete cytotoxic effect of $\beta$-eudesmol. Combination of $\beta$-eudesmol with 5 -FU or DOX resulted in a markedly enhanced cytotoxic effect of each drug in concentration- and time-dependent manners (Fig. 2b-e). The cytotoxic activity of 5-FU was increased by 24 and $55 \%$ at 24 and $48 \mathrm{~h}$ of $\beta$-eudesmol exposure, respectively. The enhancement effect of $\beta$-eudesmol on the cytotoxic activity of DOX by greater than $80 \%$ was observed following 24 and $48 \mathrm{~h}$ of exposure.

Inhibitory effects of $\beta$-eudesmol in combination with 5-FU or DOX on CCA cell migration

Based on the wound closure assay, closure of the scratched wound of the monolayer culture of KKU-100 cells significantly occurred following exposure to $\beta$-eudesmol $(30 \mu \mathrm{M})$ with or without 5 -FU $(30 \mu \mathrm{M})$ or DOX $(0.1 \mu \mathrm{M})$ for $48 \mathrm{~h}$ (Fig. 3a and b).

\section{Enhancing effect of $\beta$-eudesmol on apoptotic activities of} 5-FU and DOX on CCA cells

Annexin V/PI and DAPI staining assay was used to further examine whether KKU-100 cell death following exposure to $\beta$-eudesmol in combination with 5 -FU or DOX was associated with cell apoptosis (Fig. 4, 5 and 6). Percentage of annexin V/PI stained cells following exposure to $\beta$-eudesmol in combination with 5 -FU or DOX (Fig. 4e, f) was compared with that following exposure to each compound alone (Fig. $4 \mathrm{~b}-\mathrm{d}$ ). The calculated percentage of the stained cells is shown in Fig. 4g. The inducing effect of $\beta$-eudesmol $(30 \mu \mathrm{M})$ alone on cell apoptosis was relatively weak but was markedly increased in the presence of 5-FU or DOX. This observation of the enhancing cytotoxic activities of 5-FU or DOX by $\beta$-eudesmol through induction of cell apoptosis was supported by the analysis of cell morphology after staining with DAPI (Fig. 5). The number of apoptotic cells, nuclear condensation, and fragmentation were more prominent following exposure to the combination of $\beta$-eudesmol and 5-FU or DOX (Fig. 5e, f) compared with 5-FU or DOX alone (Fig. 5b-d).

\section{Enhancing effect of $\beta$-eudesmol on caspase activation on CCA cells by 5 -FU and DOX}

To demonstrate the mechanisms underlying apoptotic induction, activation of caspase $3 / 7$ of the cell apoptosis cascade was investigated following exposing the KKU-100 cells to $\beta$-eudesmol in combination with 5-FU or DOX. The caspase $3 / 7$ activity of the cells in the presence of $\beta$-eudesmol alone $(30 \mu \mathrm{M})$ was slightly but significantly increased compared with untreated control cells. However, the activity was markedly increased following exposure to $\beta$-eudesmol $(30 \mu \mathrm{M})$ in combination
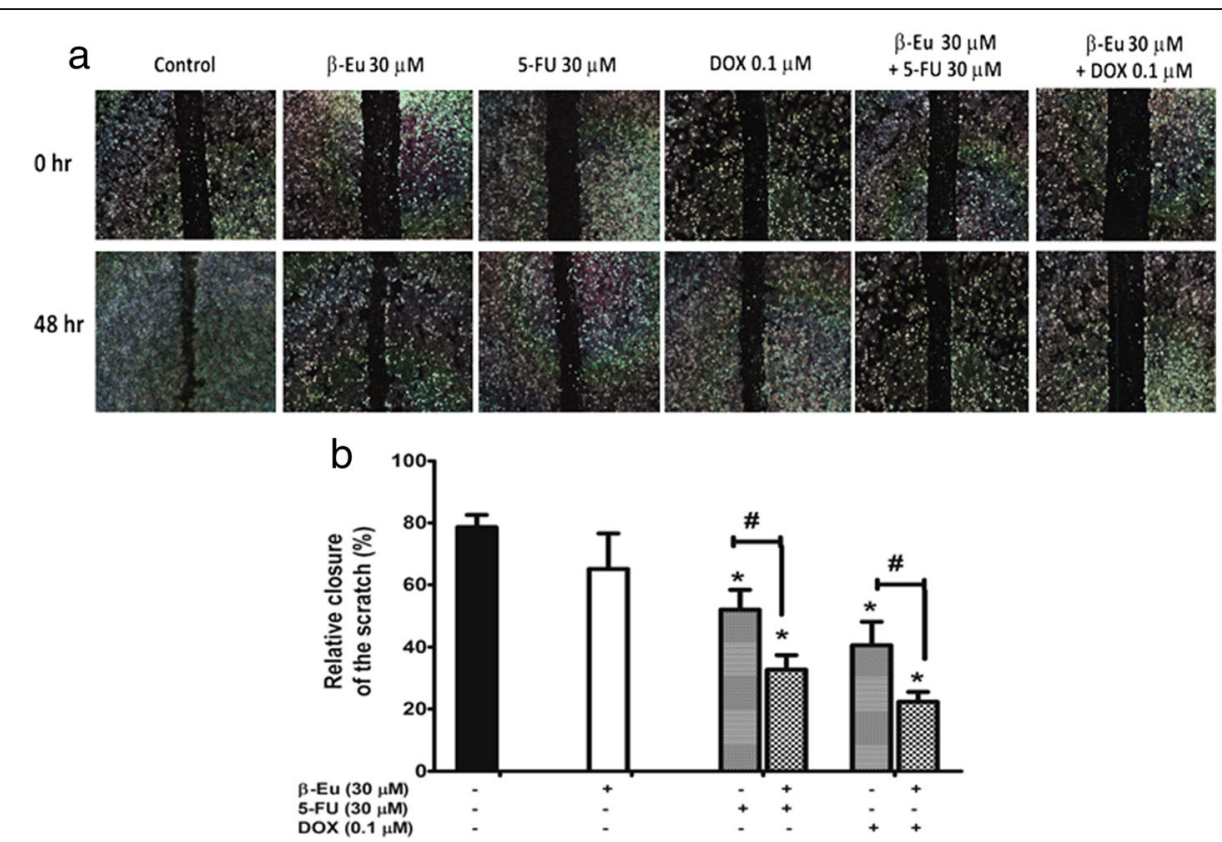

Fig. 3 Inhibitory effects of $\beta$-eudesmol in combination with 5-FU or DOX on CCA cells migration. Scratched wounds of monolayer KKU-100 cells were exposed to $\beta$-eudesmol $(30 \mu \mathrm{M}), 5-\mathrm{FU}(30 \mu \mathrm{M})$, DOX $(0.1 \mu \mathrm{M})$, and the combination of $\beta$-eudesmol $(30 \mu \mathrm{M})$ with 5 -FU (30 $\mu \mathrm{M})$ or DOX $(0.1 \mu \mathrm{M})$. Cell migration was monitored under phase-contrast microscopy ( $\times 4$ magnification). Representative images of wound healing were obtained at the time of the scratch and $48 \mathrm{~h}$ later (a). $\mathbf{b}$ The graph shows the level of cell migration into the wound scratch quantified as the percentage of wound closure at $48 \mathrm{~h}$. Each bar represents mean \pm SD of three independent experiments, triplicate each. * indicates statistically significant difference with each drug alone (paired t-test, $p<0.05$ ). $\beta$-Eu $=\beta$-Eudesmol, 5-FU $=5$-Fluorouracil, DOX $=$ Doxorubicin 

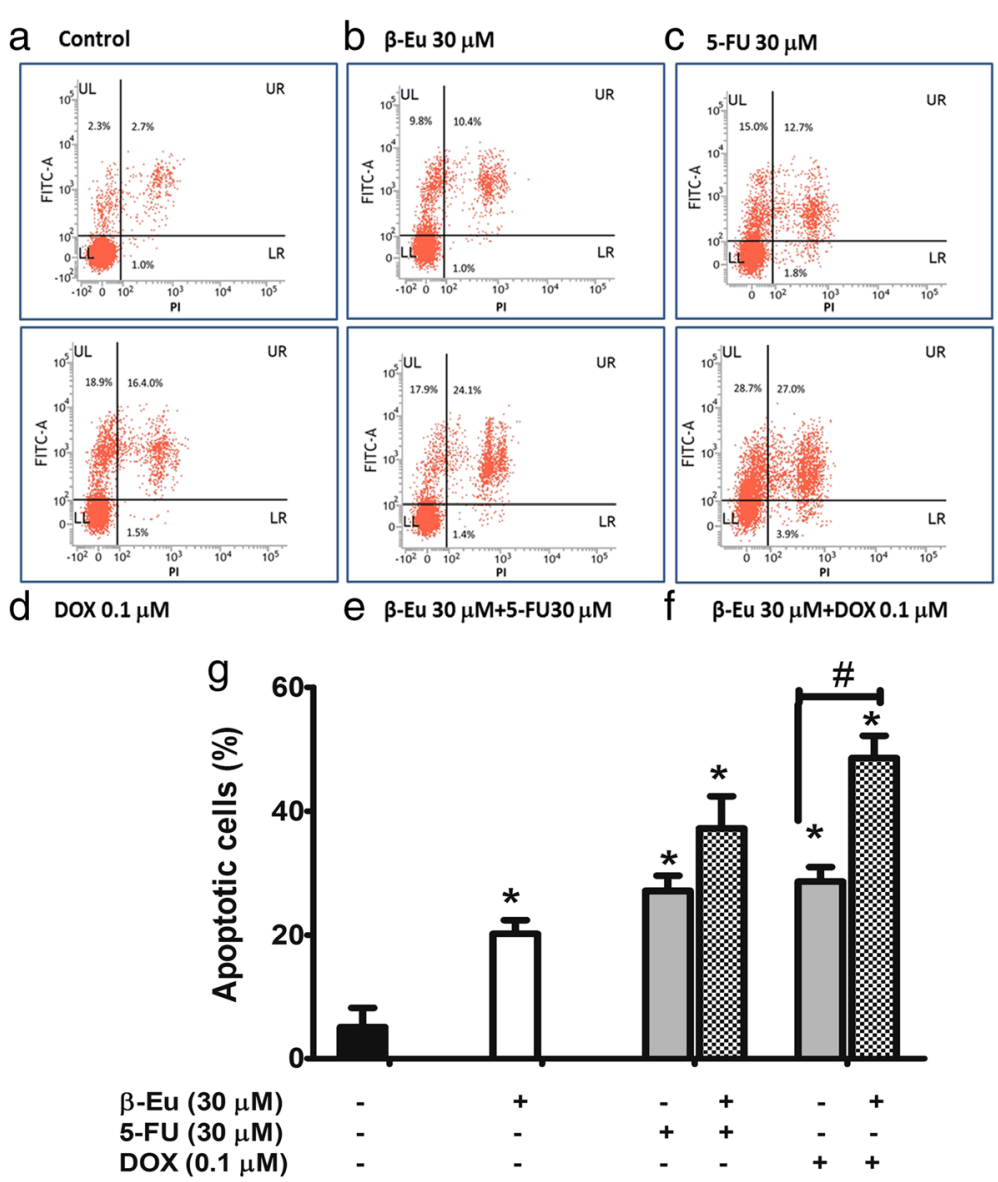

Fig. 4 Enhancing the effect of $\beta$-eudesmol on apoptotic activities of 5-FU and DOX on CCA cells. Flow cytometry analyses of KKU-100 cells using double staining with annexin $\mathrm{V}$ (annexin $\mathrm{V}$, vertical line) and propidium iodide (PI, horizontal line). a control, b $\beta$-eudesmol ( $30 \mu \mathrm{M})$, c 5 -FU $(30 \mu \mathrm{M}), \mathbf{d}$ DOX $(0.1 \mu \mathrm{M})$, e combination of $\beta$-eudesmol $(30 \mu \mathrm{M})$ with 5 -FU $(30 \mu \mathrm{M})$, and $\mathbf{f}$ combination of $\beta$-eudesmol $(30 \mu \mathrm{M})$ with DOX (0.1 $\mu \mathrm{M})$ for $24 \mathrm{~h}$. Flow cytometry apoptotic results are shown in four subpopulations which indicate: early apoptotic cells (upper left), late apoptotic cells (upper right), normal cells (lower left) and necrotic cells (lower right). $\mathbf{g}$ The levels of KKU-100 cell apoptosis expressed as the percentage of apoptotic cells are depicted in the graph (mean \pm SD averaged from three independent experiments, triplicate each). ${ }^{*} p<0.05$ vs untreated control. ${ }^{\#} p<0.05$ vs chemotherapeutic agents alone. ${ }^{*}$ indicates statistically significant difference with each drug alone (paired t-test, $\left.p<0.05\right)$. $\beta$-Eu $=\beta$-Eudesmol, 5-FU $=5$-Fluorouracil, DOX $=$ Doxorubicin

with 5-FU $(30 \mu \mathrm{M})$ or DOX $(0.1 \mu \mathrm{M})$ for $24 \mathrm{~h}$ (Fig. 6). These results suggested that combination of $\beta$-eudesmol and 5-FU or DOX enhanced KKU-100 cell apoptosis through caspase $3 / 7$ activation.

\section{Potentiating effect of $\beta$-eudesmol on suppression $\mathrm{BCl}-2$} and Bax protein expression of CCA cells by 5 -FU and DOX and the involvement of mitochondrial pathway

The NQO1 enzyme activity and protein expression in KKU-100 cells were determined to examine whether the potentiating effect of $\beta$-eudesmol on cytotoxic activities of 5-FU or DOX was mediated through suppression of oxidative stress produced by NQO1. Cells were treated with $\beta$-eudesmol with or without 5 -FU $(30 \mu \mathrm{M})$ or DOX $(0.1 \mu \mathrm{M})$ for $24 \mathrm{~h}$. 5-FU and DOX alone significantly enhanced NQO1 activity and protein expression in KKU-100 cells. In the presence of $\beta$-eudesmol however, enzyme activity and protein expression were markedly decreased (Fig. 7a and b).

In order to further confirm the involvement of the mitochondrial pathway in $\beta$-eudesmol enhanced chemosensitivity of KKU-100 cells through the induction of cell apoptosis, the expression levels of Bcl-2 family proteins $\mathrm{Bcl}-2$ and $\mathrm{Bax}$ were investigated by Western blot analysis. $\beta$-Eudesmol $(30 \mu \mathrm{M})$ alone did not alter Bax and $\mathrm{Bcl}-2$ protein expression. On the other hand, the combination of $\beta$-eudesmol with 5 -FU $(30 \mu \mathrm{M})$ or DOX $(0.1 \mu \mathrm{M})$ significantly increased the $\mathrm{Bax} / \mathrm{Bcl}-2$ expression ratios (1.23 vs. 2.81 and 1.84 vs. 2.98 for 5 -FU alone vs. 5 -FU $+\beta$-eudesmol and DOX alone vs. DOX $+\beta$-eudesmol, respectively) (Fig. 7b). These results suggested that $\beta$-eudesmol-potentiated cytotoxic activity of 5-FU and DOX was mediated through induction of apoptosis by Bcl-2 protein family in the mitochondrial pathway. 

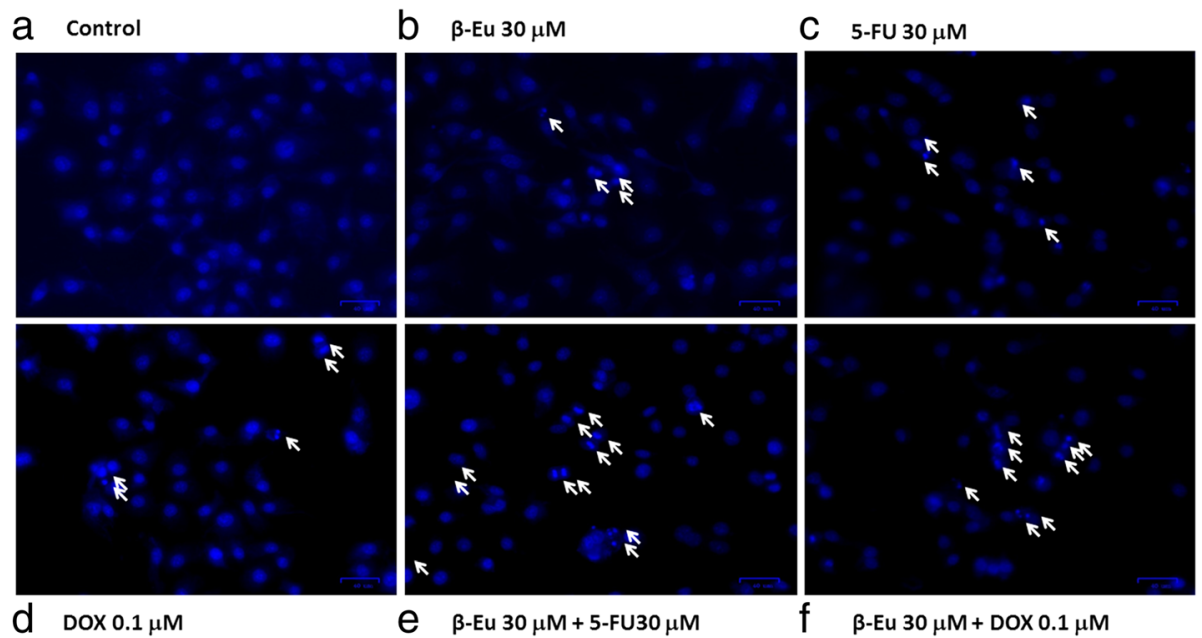

Fig. 5 Apoptotic bodies of KKU-100 CCA cells following treatment with $\beta$-eudesmol, 5-FU, and DOX, and the combination of $\beta$-eudesmol with 5 -FU or DOX by DAPI staining. a control, b $\beta$-eudesmol $(30 \mu \mathrm{M}), \mathbf{c} 5$-FU $(30 \mu \mathrm{M}), \mathbf{d}$ DOX $(0.1 \mu \mathrm{M})$, e combination of $\beta$-eudesmol (30 $\mu \mathrm{M})$ with 5-FU $(30 \mu \mathrm{M})$, and $\mathbf{f}$ combination of $\beta$-eudesmol $(30 \mu \mathrm{M})$ with DOX $(0.1 \mu \mathrm{M})$ for $24 \mathrm{~h}$. Apoptotic bodies were observed under inverted fluorescence microscopy (Scale bars represent $40 \mu \mathrm{m}$ ). $\beta$-Eu= $\beta$-Eudesmol, 5-FU=5-Fluorouracil, DOX= Doxorubicin

\section{Discussion}

Since the up-regulation of NQO1 in certain types of solid tumor including CCA was associated with poor prognosis [14-19], compounds targeting NQO1 would be of therapeutic potential. Previous studies have suggested possible role of NQO1 suppression-enhanced chemosensitivity of the cancer cells. Dicoumarol, a potent inhibitor of the NQO1 enzyme, has been shown to increase sensitivity of CCA cells to chemotherapeutic agents [22]. Furthermore, NQO1 silencing by gene knockdown in conjunction with chemotherapeutic agents has been shown to suppress the replication capacity of CCA cells [23]. In the present study, $\beta$-eudesmol suppressed NQO1 enzyme activity in KKU-100 cells with moderate potency compared with dicoumarol, the most potent inhibitor of NQO1 [28]. Direct addition of $\beta$-eudesmol to cell lysates significantly inhibited NQO1 activity at all concentrations. At highest concentration (100 $\mu \mathrm{M}, 95.56 \%$ inhibition), the extent of the inhibitory activity was almost similar to that of dicoumarol (1 $\mu \mathrm{M}, 99.21 \%$ inhibition). On the other hand, significant suppression of NQO1 protein expression was observed only at the highest concentration $(100 \mu \mathrm{M})$ compared with that inhibited enzyme activity both in the cells (at the lowest concentration of $30 \mu \mathrm{M}$ ) and cell lysates (at the lowest concentration of $1 \mu \mathrm{M})$. Dicoumarol has been shown to exert no or little effect on CCA NQO1 protein expression [42]. It is possible that $\beta$-eudesmol-mediated NQO1 suppression was through direct inhibition of the enzyme activity with similar mechanism of that observed with dicoumarol. The suppression of NQO1 activity by dicoumarol is a consequence of its competition with $\mathrm{NAD}(\mathrm{P}) \mathrm{H}$ for binding to $\mathrm{NQO} 1$ and prevention of electron transfer to FAD co-factor, allowing the quinone substrate to bind the enzyme and to be reduced [43]. It is well established that NQO1 functions as a detoxification and antioxidant enzyme that protects cells from oxidative stress. Additionally, it also functions as a p53 wild-type stabilizer by interference with 20s proteasome-mediated degradation of p53 [44]. P53 is a tumor suppressor gene which functions in response to stimulation by DNA damage, oxidative stress, or cell cycle abnormalities $[44,45]$. The anticancer and apoptotic activity of P53 involves several mechanisms [46]. In the present study, $\beta$-eudesmol was shown to enhance chemosensitivity-induced apoptosis of CCA cells which was linked with suppression of NQO1 activity. So far, the previously reported role of NQO1 suppression on p53 modulation and cell apoptosis remains controversial. Inhibition of NQO1 by natural inhibitor curcumin has been shown to suppress p53 protein levels and p53-induced apoptosis of cancer cells in the NQO1-dependent pathway [26]. On the other hand, dicoumarol or NQO1 knockdown cells was shown to enhance p53 protein levels which was associated with induction of apoptosis in CCA $[22,23]$ and urogenital cancer cells [20]. The CCA-KKU-100 cell used in the present study was shown to express both the wild-type full-length p53 and the splicing variant of the truncated p53 protein [47]. Interestingly, our results showed that the potentiating effect of NQO1 suppression by $\beta$-eudesmol on the cytotoxicity and apoptotic activity of 5-FU and DOX occurred even in such the CCA cells with a high expression ratio of mutant p53/wild-type p53. The exact molecular action on NQO1 activity of $\beta$-eudesmol needs further investigation. It is yet to investigate the 


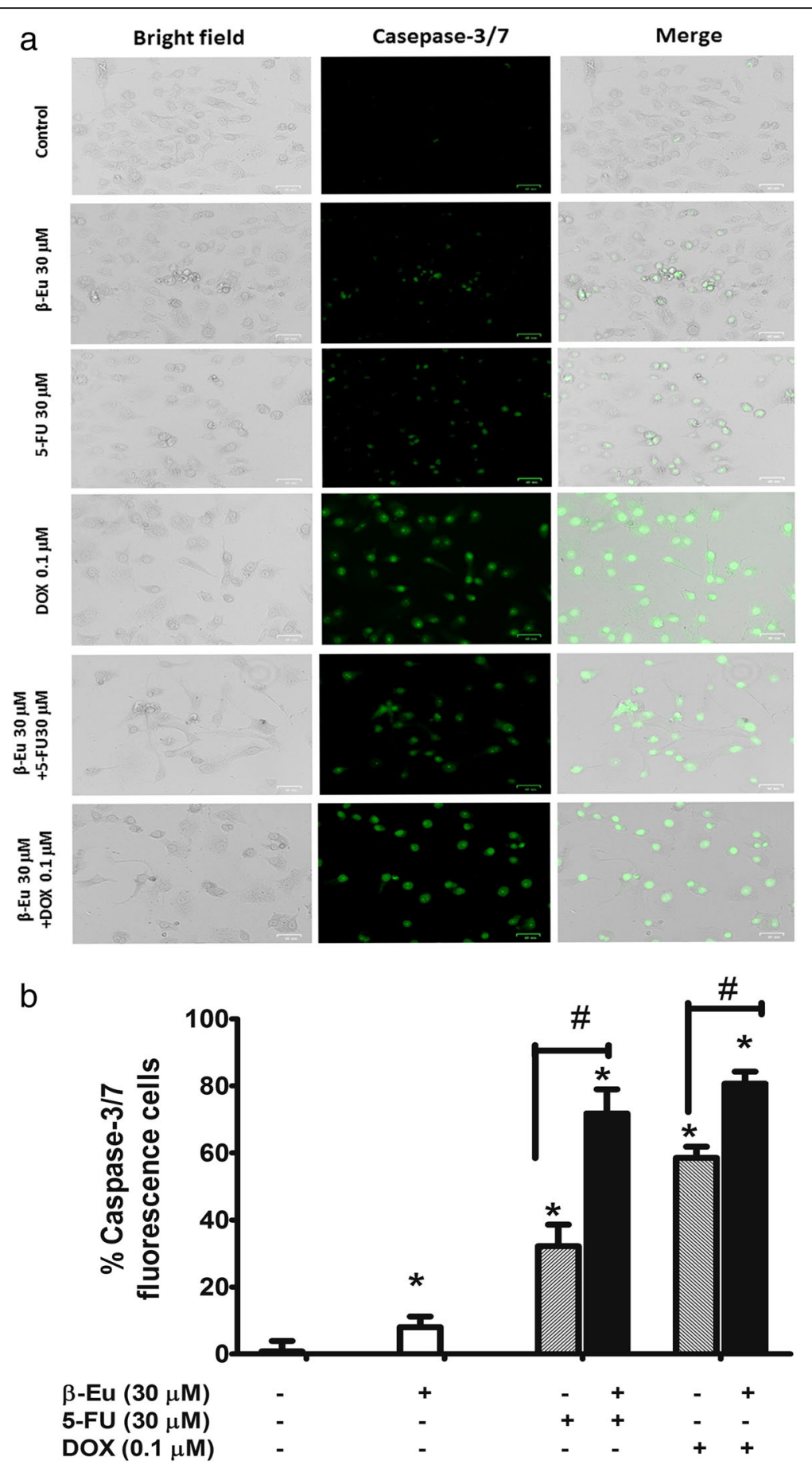

Fig. 6 Caspase-3/7 activation in KKU-100 cells following treatment with $\beta$-eudesmol, 5-FU, and DOX, and the combination of $\beta$-eudesmol and 5-FU or DOX detected by fluorescence microscopy. a KKU-100 cells were treated with $30 \mu \mathrm{M}$ of $\beta$-eudesmol, $30 \mu \mathrm{M}$ of 5-FU, $0.1 \mu \mathrm{M}$ of DOX and $\beta$-eudesmol $(30 \mu \mathrm{M})$ combined with 5-FU $(30 \mu \mathrm{M})$ or DOX $(0.1 \mu \mathrm{M})$ for $24 \mathrm{~h}$ and labeled with CellEvent ${ }^{\oplus}$ Caspase $3 / 7$ Green Detection Reagent and examined under the fluorescence microscope. Left panel, the grey image reveals KKU-100 CCA cells in the field of view. Middle and right panel show apoptotic caspase 3/7 positive cells green fluorescent in the same area of interest. Data are representative of at least 4-5 randomly selected fields' images with similar results. Morphological changes were evaluated under a microscope. There were shrink and blabbing cells treated with $\beta$-eudesmol with or without 5-FU or DOX, indicating apoptosis induction. The scale bar corresponds to $40 \mu \mathrm{m}$. $\mathbf{b}$ The graph shows the level of caspase-3/7 activity as the percentage of caspase-3/7 fluorescent cells expression at $24 \mathrm{~h}$. Data are presented as mean \pm SD of three independent experiments, triplicate each. * indicates statistically significant difference with each drug alone (paired t-test, $p<0.05$ ). $\beta$-Eu= $\beta$-Eudesmol, 5-FU $=5$-Fluorouracil, DOX= Doxorubicin 


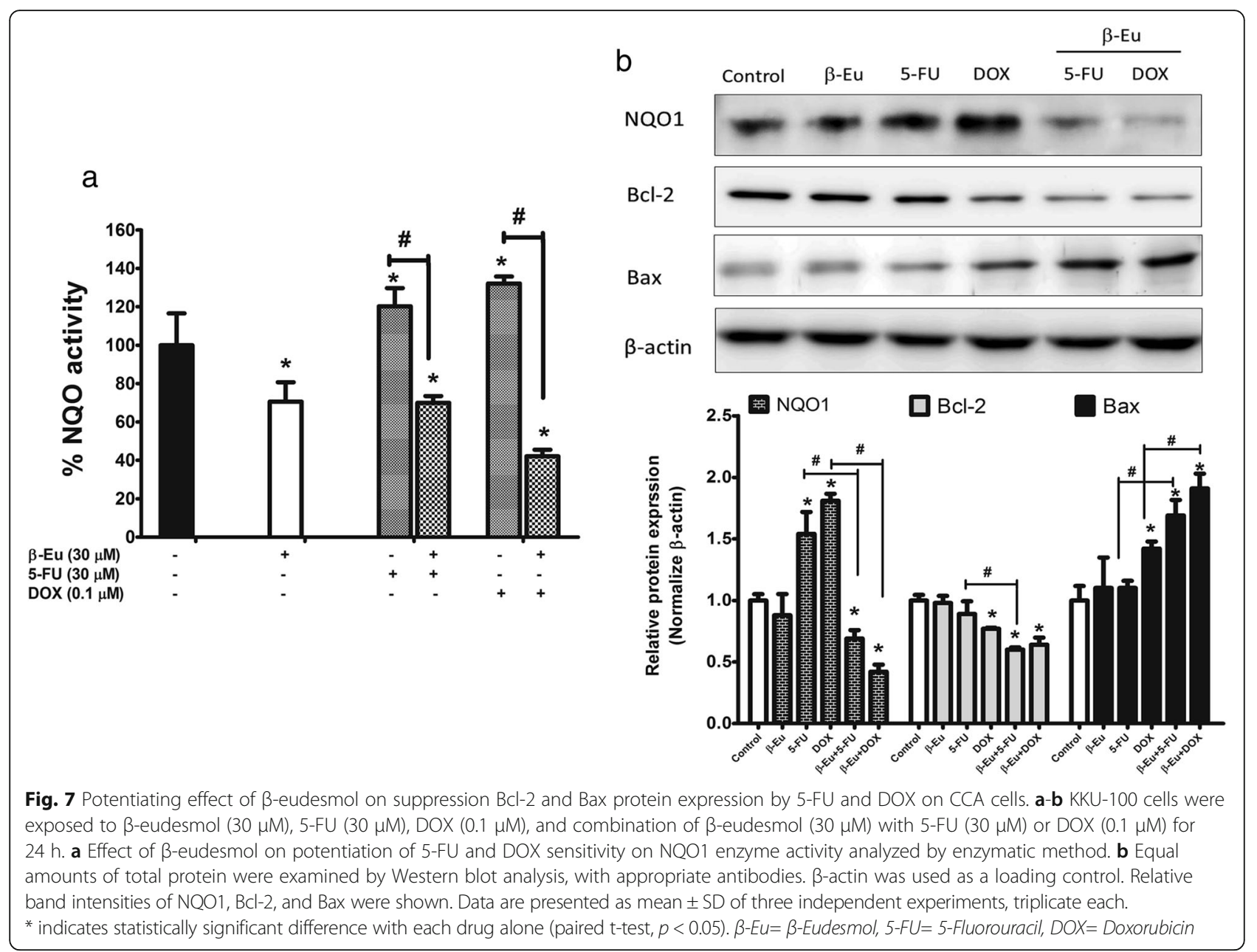

chemosensitizing effect of NQO1 suppression by $\beta$-eudesmol on CCA cells which express other p53 mutation variants.

5-FU and DOX are widely used for chemotherapy of several types of cancer including CCA. However, the effectiveness of both drugs in the treatment of recurrent/ metastatic cancers is limited due to acquired or intrinsic resistance of the cancer cells. $\beta$-Eudesmol was shown to suppress NQO1 enzyme activity and protein expression and thereby, potentiating the cytotoxic activity of both drugs in KKU-100 cells. Combination of both conventional drugs with $\beta$-eudesmol may be an effective therapeutic strategy for targeting chemoresistant CCA as well as improving therapeutic efficacy and minimizing toxicity of conventional drugs. The enhancement of CCA cell sensitivity has also been reported when conventional chemotherapeutics are used in conjunction with NQO1 knockdown [23].

Metastasis is one of the most important characteristics of cancers indicating poor prognosis and death in cancer patients. The process reflects the ability of cancer cells to break away from the main tumor and enter the bloodstream or lymphatic system. The key steps include degradation of tumor extracellular matrix, cell invasion, and cell migration [48]. Inhibitors of these metastasis-associated processes would, therefore, provide a significant impact on cancer chemoprevention and chemotherapy. Previous studies have shown that NQO1 is one of the enzymes that play an important role in cancer cell migration and invasion of human aortic vascular smooth muscle cells. The NQO1 inhibitor dicoumarol or NQO1 knockdown was shown to suppress matrix metallopeptidase 9 (MMP 9) expression and tumor necrosis factor $\alpha$ (TNF- $\alpha)$-induced cell migration [49]. In the present study, treatment of KKU-100 cells with $\beta$-eudesmol markedly decreased cancer cell migration mediated by 5 -FU or DOX. It is of note that this antimigratory effect of $\beta$-eudesmol was detected at a concentration that significantly inhibited NQO1 expression (>40\%) with minimal cytotoxic effect to KKU-100 cells. The chemosensitivity enhancing effect of $\beta$-eudesmol on the CCA cell could at least in part, be a consequence of its inhibitory effect on CCA cell metastasis. 
The process of programmed cell death or apoptosis is generally characterized by a programmed sequence of events leading to the eradication of cells without releasing damaging substances into the surrounding area [50]. Initiation of apoptosis process therefore, benefits cancer cells. The mechanism through which $\beta$-eudesmol mediated suppression of NQO1-induced cell death was further explored in the present study. $\beta$-Eudesmol was shown to significantly enhance proapoptotic activities of both 5-FU and DOX. During the steps of apoptosis, the cells shrunk despite undamaged membranes. Cells with DNA fragmentation, condensed chromatin, and nuclear pyknosis were detected by DAPI. Combination of $\beta$-eudesmol and 5-FU or DOX markedly increased apoptotic bodies. Induction of cell apoptosis by $\beta$-eudesmol was also observed in other cancer cells, i.e., human hepatocellular carcinoma [51] and human leukemia cells [52]. Apoptosis process is finely regulated at gene level resulting in the orderly and efficient removal of damaged cells such as those occurring following DNA damage or during development. The balance between the proapoptotic (Bax) and anti-apoptotic (Bcl-2) protein regulators is a critical key point to determine cell apoptosis. The apoptotic activity of various compounds has been evaluated by measuring caspase activity particularly caspase $3 / 7$ activity which is the final step in both the intrinsic or extrinsic pathways of apoptosis [53]. In this study, the combination of $\beta$-eudesmol and 5-FU or DOX significantly activated caspase $3 / 7$ activity compared to each drug alone. The $\beta$-eudesmol-induced enhacement of chemosensitivity of CCA cells by promoting their apoptosis was shown to be associated with increase of the $\mathrm{Bax} / \mathrm{Bcl}-2$ ratio and caspase activation. The Bcl-2 family is a key factor in the regulation of cell homeostasis which is directly associated with cell survival and cell death. The process that promotes pro-apoptotic factor Bax expression or/and decreases anti-apoptotic factor Bcl-2 expression results in the release of cytochrome to the cytosol and subsequently, initiation of caspase 9 and caspase 3 cascades, leading to cell apoptosis [39, 40]. .Our results indicated that $\beta$-eudesmol in combination with 5-FU or DOX stimulated the expression of $\mathrm{Bax}$ protein while decreasing the expression of $\mathrm{Bcl}-2$.

\section{Conclusions}

The cytotoxic activity of $\beta$-eudesmol was at least in part, mediated through suppression of NQO1. Induction of cell apoptosis and activation of caspase 3/7, up-regulation of $\mathrm{Bax}$ and down-regulation of $\mathrm{Bcl}-2$ proteins could contribute to its cytotoxic and proapoptotic activity. $\beta$-Eudesmol may serve as a potential anti-CCA candidate particularly when used in combination with conventional chemotherapeutics. Further investigations in animal models are needed to confirm its potential clinical use.

\section{Abbreviations}

5-FU: 5-Fluorouracil; CCA: Cholangiocarcinoma; DMSO: Dimethyl sulfoxide; DOX: Doxorubicin; DTT: Dithiothreitol; FBS: Fetal bovine serum; NQO1: NAD(P)H-quinone oxidoreductase 1; PMSF: Phenylmethylsulfonyl fluoride; PVDF: Polyvinylidene difluoride; $\beta$-Eu: $\beta$-Eudesmol;

Tween-20: Polyethylene glycol sorbitan monolaurate

\section{Acknowledgments}

We would like to thank Professor Banchob Sripa, Department of Pathology, Faculty of Medicine, Khon Kean University, for providing KKU-100 cell.

\section{Funding}

This present study was supported by Chulabhorn International College of Medicine (CICM2015), and Center of Excellence in Pharmacology and Molecular Biology of Malaria and Cholangiocarcinoma, Thammasat University, Thailand (2015).

\section{Availability of data and materials}

All data and materials are contained and described in the manuscript.

\section{Authors' contributions}

PS and KNB contributed to the conception and design of the entire study. PS carried out most of the experiments, contributed to the data interpretation. SP contributed to the analysis of cell apoptosis and caspase-3/ 7 activation. KBN provided grant support, funding and the final editing of the manuscript. All contributed to data interpretation, drafting and final editing of the manuscript. All authors read and approved the final manuscript.

Ethics approval and consent to participate

Not applicable.

Consent for publication

Not applicable.

Competing interests

The authors declare that they have no competing interests.

\section{Publisher's Note}

Springer Nature remains neutral with regard to jurisdictional claims in published maps and institutional affiliations.

Received: 11 March 2018 Accepted: 10 June 2018

Published online: 19 June 2018

\section{References}

1. Cardinale V, Semeraro R, Torrice A, Gatto M, Napoli C, Bragazzi MC, et al. Intra-hepatic and extra-hepatic cholangiocarcinoma: new insight into epidemiology and risk factors. World J Gastrointest Oncol. 2010;2(11):407-16.

2. Kamsa-ard S, Wiangnon S, Suwanrungruang K, Promthet S, Khuntikeo N, Kamsa-ard S, et al. Trends in liver cancer incidence between 1985 and 2009, Khon Kaen, Thailand: cholangiocarcinoma. Asian Pac J Cancer Prev. 2011;12(9):2209-13.

3. Sripa B, Pairojkul C. Cholangiocarcinoma: lessons from Thailand. Curr Opin Gastroenterol. 2008;24(3):349-56.

4. Sripa B, Brindley PJ, Mulvenna J, Laha T, Smout MJ, Mairiang E, et al. The tumorigenic liver fluke Opisthorchis viverrini-multiple pathways to cancer. Trends Parasitol. 2012;28(10):395-407.

5. Khan SA, Thomas HC, Davidson BR, Taylor-Robinson SD. Cholangiocarcinoma. Lancet. 2005;366(9493):1303-14.

6. Hezel AF, Zhu AX. Systemic therapy for biliary tract cancers. Oncologist. 2008:13(4):415-23.

7. Fodale $\mathrm{V}$, Pierobon M, Liotta L, Petricoin E. Mechanism of cell adaptation: when and how do cancer cells develop chemoresistance? Cancer J. 2011;17(2):89-95.

8. Holohan C, Van Schaeybroeck S, Longley DB, Johnston PG. Cancer drug resistance: an evolving paradigm. Nat Rev Cancer. 2013;13(10):714-26.

9. Ross D, Kepa JK, Winski SL, Beall HD, Anwar A, Siegel D. NAD(P)H:quinone oxidoreductase 1 (NQO1): chemoprotection, bioactivation, gene regulation and genetic polymorphisms. Chem Biol Interact. 2000;129(1-2):77-97.

10. Siegel D, Ross D. Immunodetection of $\mathrm{NAD}(\mathrm{P}) \mathrm{H}$ :quinone oxidoreductase 1 (NQO1) in human tissues. Free Radic Biol Med. 2000;29(3-4):246-53. 
11. Strassburg A, Strassburg CP, Manns MP, Tukey RH. Differential gene expression of $\mathrm{NAD}(\mathrm{P}) \mathrm{H}$ :quinone oxidoreductase and $\mathrm{NRH}$ :quinone oxidoreductase in human hepatocellular and biliary tissue. Mol Pharmacol. 2002;61(2):320-5.

12. Dinkova-Kostova AT, Talalay P. NAD(P)H: quinone acceptor oxidoreductase 1 (NQO1), a multifunctional antioxidant enzyme and exceptionally versatile cytoprotection. Arch Biochem Biophys. 2010;501(1):116-23.

13. Joseph P, Long DJ 2nd, Klein-Szanto AJ, Jaiswal AK. Role of NAD(P)H: quinone oxidoreductase 1 (DT diaphorase) in protection against quinone toxicity. Biochem Pharmacol. 2000;60(2):207-14.

14. Cui $X$, Jin T, Wang $X$, Jin G, Li Z, Lin L. NAD(P)H:quinone oxidoreductase-1 overexpression predicts poor prognosis in small cell lung cancer. Oncol Rep. 2014;32(6):2589-95.

15. Ji M, Jin A, Sun J, Cui X, Yang Y, Chen L, et al. Clinicopathological implications of $\mathrm{NQO} 1$ overexpression in the prognosis of pancreatic adenocarcinoma. Oncol Lett. 2017;13(5):2996-3002.

16. Glorieux C, Sandoval JM, Dejeans N, Ameye G, Poirel HA, Verrax J, et al. Overexpression of $\mathrm{NAD}(\mathrm{P}) \mathrm{H}$ :quinone oxidoreductase 1 (NQO1) and genomic gain of the NQO1 locus modulates breast cancer cell sensitivity to quinones. Life Sci. 2016;145:57-65.

17. Jin Z, Cui $X$, Zhang $Y$, Yang $Y$, Li L, Lin Z, et al. Significance of NAD (P) H: quinone oxidoreductase 1 overexpression in prognostic evaluation of thyroid medullary carcinoma. Zhonghua Bing Li Xue Za Zhi. 2015;44(2):128-9.

18. Lin L, Qin Y, Jin T, Liu S, Zhang S, Shen X, et al. Significance of NQO1 overexpression for prognostic evaluation of gastric adenocarcinoma. Exp Mol Pathol. 2014;96(2):200-5.

19. Buranrat B, Chau-in S, Prawan A, Puapairoj A, Zeekpudsa P, Kukongviriyapan V. NQO1 expression correlates with cholangiocarcinoma prognosis. Asian Pac J Cancer Prev. 2012;13(Suppl):131-6.

20. Matsui Y, Watanabe J, Ding S, Nishizawa K, Kajita Y, Ichioka K, et al. Dicoumarol enhances doxorubicin-induced cytotoxicity in p53 wild-type urothelial cancer cells through p38 activation. BJU Int. 2010;105(4):558-64.

21. Watanabe J, Nishiyama H, Matsui $Y$, Ito M, Kawanishi H, Kamoto T, et al. Dicoumarol potentiates cisplatin-induced apoptosis mediated by c-Jun $\mathrm{N}$-terminal kinase in p53 wild-type urogenital cancer cell lines. Oncogene. 2006:25(17):2500-8.

22. Buranrat B, Prawan A, Kukongviriyapan U, Kongpetch S, Kukongviriyapan V. Dicoumarol enhances gemcitabine-induced cytotoxicity in high NQO1expressing cholangiocarcinoma cells. World J Gastroenterol. 2010;16(19):2362-70

23. Zeekpudsa P, Kukongviriyapan V, Senggunprai L, Sripa B, Prawan A. Suppression of $\mathrm{NAD}(\mathrm{P}) \mathrm{H}$-quinone oxidoreductase 1 enhanced the susceptibility of cholangiocarcinoma cells to chemotherapeutic agents. J Exp Clin Cancer Res. 2014;33:11

24. Colucci MA, Reigan P, Siegel D, Chilloux A, Ross D, Moody CJ. Synthesis and evaluation of 3-aryloxymethyl-1,2-dimethylindole-4,7-diones as mechanismbased inhibitors of $\mathrm{NAD}(\mathrm{P}) \mathrm{H}$ :quinone oxidoreductase 1 (NQO1) activity. J Med Chem. 2007;50(23):5780-9.

25. Nolan KA, Zhao H, Faulder PF, Frenkel AD, Timson DJ, Siegel D, et al. Coumarin-based inhibitors of human NAD(P)H:quinone oxidoreductase-1. Identification, structure-activity, off-target effects and in vitro human pancreatic cancer toxicity. J Med Chem. 2007;50(25):6316-25.

26. Tsvetkov P, Asher G, Reiss V, Shaul Y, Sachs L, Lotem J. Inhibition of $\mathrm{NAD}(\mathrm{P}) \mathrm{H}$ :quinone oxidoreductase 1 activity and induction of p53 degradation by the natural phenolic compound curcumin. Proc Natl Acad Sci U S A. 2005;102(15):5535-40.

27. Chen S, Hwang J, Deng PS. Inhibition of NAD(P)H:quinone acceptor oxidoreductase by flavones: a structure-activity study. Arch Biochem Biophys. 1993;302(1):72-7.

28. Chen S, Wu K, Zhang D, Sherman M, Knox R, Yang CS. Molecular characterization of binding of substrates and inhibitors to DT-diaphorase: combined approach involving site-directed mutagenesis, inhibitor-binding analysis, and computer modeling. Mol Pharmacol. 1999;56(2):272-8.

29. Na-Bangchang K, Karbwang J. Traditional herbal medicine for the control of tropical diseases. Trop Med Health. 2014;42(2 Suppl):3-13.

30. Ji L, Ao P, Pan JG, Yang JY, Yang J, Hu SL. GC-MS analysis of essential oils from rhizomes of Atractylodes lancea (Thunb.) DC. and A. Chinensis (DC.) Koidz. Zhongguo Zhong Yao Za Zhi. 2001;26(3):182-5.

31. Duan JA, Wang L, Qian S, Su S, Tang Y. A new cytotoxic prenylated dihydrobenzofuran derivative and other chemical constituents from the rhizomes of Atractylodes lancea DC. Arch Pharm Res. 2008;31(8):965-9.
32. Zhao M, Wang $Q$, Ouyang Z, Han B, Wang W, Wei $Y$, et al. Selective fraction of Atractylodes lancea (Thunb.) DC. and its growth inhibitory effect on human gastric cancer cells. Cytotechnology. 2014;66(2):201-8.

33. Mahavorasirikul W, Viyanant V, Chaijaroenkul W, Itharat A, Na-Bangchang K. Cytotoxic activity of Thai medicinal plants against human cholangiocarcinoma, laryngeal and hepatocarcinoma cells in vitro. BMC Complement Altern Med. 2010;10:55

34. Plengsuriyakarn T, Karbwang J, Na-Bangchang K. Anticancer activity using positron emission tomography-computed tomography and pharmacokinetics of beta-eudesmol in human cholangiocarcinoma xenografted nude mouse model. Clin Exp Pharmacol Physiol. 2015;42(3):293-304.

35. Plengsuriyakarn $T$, Viyanant $V$, Eursitthichai $V$, Picha $P$, Kupradinun $P$, Itharat $A$, et al. Anticancer activities against cholangiocarcinoma, toxicity and pharmacological activities of Thai medicinal plants in animal models. BMC Complement Altern Med. 2012;12:23.

36. Yu F, Harada H, Yamasaki K, Okamoto S, Hirase S, Tanaka Y, et al. Isolation and functional characterization of a beta-eudesmol synthase, a new sesquiterpene synthase from Zingiber zerumbet Smith. FEBS Lett. 2008; 582(5):565-72.

37. Wang CC, Lin SY, Cheng HC, Hou WC. Pro-oxidant and cytotoxic activities of atractylenolide I in human promyeloleukemic HL-60 cells. Food Chem Toxicol. 2006:44(8):1308-15.

38. Salleh NA, Ismail S, Ab Halim MR. Effects of Curcuma xanthorrhiza extracts and their constituents on phase II drug-metabolizing enzymes activity. Pharm Res. 2016;8(4):309-15.

39. Mathema VB, Chaijaroenkul W, Karbwang J, Na-Bangchang K. Growth inhibitory effect of beta-eudesmol on cholangiocarcinoma cells and its potential suppressive effect on heme oxygenase-1 production, STAT1/3 activation, and NF-kappaB downregulation. Clin Exp Pharmacol Physiol. 2017:44(11):1145-54.

40. Prochaska HJ, Santamaria AB. Direct measurement of $\mathrm{NAD}(\mathrm{P}) \mathrm{H}$ :quinone reductase from cells cultured in microtiter wells: a screening assay for anticarcinogenic enzyme inducers. Anal Biochem. 1988;169(2):328-36.

41. Senggunprai L, Kukongviriyapan V, Prawan A, Kukongviriyapan U. Quercetin and EGCG exhibit chemopreventive effects in cholangiocarcinoma cells via suppression of JAK/STAT signaling pathway. Phytother Res. 2014;28(6):841-8.

42. Chen $M$, Gong L, Qi X, Xing G, Luan $Y$, Wu Y, et al. Inhibition of renal NQ01 activity by dicoumarol suppresses nitroreduction of aristolochic acid I and attenuates its nephrotoxicity. Toxicol Sci. 2011;122(2):288-96.

43. Asher G, Dym O, Tsvetkov P, Adler J, Shaul Y. The crystal structure of $\mathrm{NAD}(\mathrm{P}) \mathrm{H}$ quinone oxidoreductase 1 in complex with its potent inhibitor dicoumarol. Biochemistry. 2006;45(20):6372-8.

44. Nioi $\mathrm{P}$, Hayes JD. Contribution of $\mathrm{NAD}(\mathrm{P}) \mathrm{H}$ :quinone oxidoreductase 1 to protection against carcinogenesis, and regulation of its gene by the Nrf2 basic-region leucine zipper and the arylhydrocarbon receptor basic helixloop-helix transcription factors. Mutat Res. 2004;555(1-2):149-71.

45. Asher G, Lotem J, Cohen B, Sachs L, Shaul Y. Regulation of p53 stability and p53-dependent apoptosis by NADH quinone oxidoreductase 1. Proc Natl Acad Sci U S A. 2001;98(3):1188-93.

46. Bouchet BP, Caron de Fromentel C, Puisieux A, Galmarini CM. p53 as a target for anti-cancer drug development. Crit Rev Oncol Hematol. 2006;58(3):190-207.

47. Nutthasirikul N, Limpaiboon T, Leelayuwat C, Patrakitkomjorn S, Jearanaikoon P. Ratio disruption of the 133p53 and TAp53 isoform equilibrium correlates with poor clinical outcome in intrahepatic cholangiocarcinoma. Int J Oncol. 2013;42(4):1181-8.

48. Friedl $P$, Wolf $K$. Tumour-cell invasion and migration: diversity and escape mechanisms. Nat Rev Cancer. 2003;3(5):362-74.

49. Lee SO, Chang YC, Whang K, Kim CH, Lee IS. Role of NAD(P)H:quinone oxidoreductase 1 on tumor necrosis factor-alpha-induced migration of human vascular smooth muscle cells. Cardiovasc Res. 2007;76(2):331-9.

50. Su Z, Yang Z, Xu Y, Chen Y, Yu Q. Apoptosis, autophagy, necroptosis, and cancer metastasis. Mol Cancer. 2015;14:48.

51. Bomfim DS, Ferraz RP, Carvalho NC, Soares MB, Pinheiro ML, Costa EV, et al. Eudesmol isomers induce caspase-mediated apoptosis in human hepatocellular carcinoma HepG2 cells. Basic Clin Pharmacol Toxicol. 2013;113(5):300-6.

52. Li Y, Li T, Miao C, Li J, Xiao W, Ma E. beta-Eudesmol induces JNK-dependent apoptosis through the mitochondrial pathway in HL60 cells. Phytother Res. 2013;27(3):338-43.

53. Mcllwain DR, Berger T, Mak TW. Caspase functions in cell death and disease. Cold Spring Harb Perspect Biol. 2013;5(4):a008656. 